\title{
Juliusz Giżyński* \\ SALDO STRUKTURALNE JAKO WSKAŹNIK OCENY POLITYKI FISKALNEJ W KRAJACH STREFY EURO
}

\begin{abstract}
Streszczenie. Głównym celem artykułu jest przedstawienie istoty salda strukturalnego w nadzorze fiskalnym strefy euro, scharakteryzowanie jego głównych aspektów metodycznych, oraz analiza kształtowania się tego salda w krajach strefy euro w okresie wychodzenia z kryzysu. Od czasu pierwszej reformy Paktu Stabilności i Wzrostu, która miała miejsce w 2005 r., saldo strukturalne odgrywa kluczową rolę w nadzorze fiskalnym w strefie euro. Saldo to jest dostosowane cyklicznie, bez uwzględnienia środków jednorazowych i tymczasowych. Umożliwia ono oszacowanie rozmiaru działań konsolidacyjnych wprowadzanych przez kraje członkowskie oraz rozpoznanie rezultatów tych działań.
\end{abstract}

Słowa kluczowe: saldo strukturalne, strefa euro, wysiłek fiskalny.

JEL: E62, H5, H6

\section{WPROWADZENIE}

W ostatnich latach saldo budżetowe sektora finansów publicznych w Unii Gospodarczej i Walutowej (UGW) podlegało znacznym fluktuacjom. Główną ich przyczyną były wahania cykliczne w gospodarce oraz działania o charakterze dyskrecjonalnym - w postaci pakietów stymulujących i konsolidacji fiskalnej - podjęte przez poszczególne kraje członkowskie. Ponadto specjalne czynniki, jak rządowe operacje stabilizujące sektor finansowy, powodowały, że na koniec 2014 r. deficyt sektora finansów publicznych (Fiscal developments 2014: 85) wciąż przekraczał wartość referencyjną 3\% PKB w dziesięciu krajach strefy euro (European Commission 2015c: 160). Należy podkreślić, iż wszystkie powyższe czynniki znajdują swój wyraz w saldzie strukturalnym (structural balance). Saldo to można zinterpretować jako część pozycji fiskalnej, która dominuje, jeśli gospodarka funkcjonuje na poziomie potencjalnym (Fiscal developments 2014: 85). Sposób oszacowania tego wskaźnika oraz identyfikacja czynników wpływających na jego ewolucję są kluczowe dla analizy polityki fiskalnej w krajach należących do UGW (The assessment of ... 2014: 73).

Głównym celem artykułu jest przedstawienie istoty salda strukturalnego w nadzorze fiskalnym strefy euro, scharakteryzowanie jego głównych aspektów metodycznych oraz analiza kształtowania się tego salda w krajach strefy euro w okresie wychodzenia z kryzysu. Artykuł przygotowano w oparciu o metodologię badawczą studiów i analizę literatury dotyczącej polityki fiskalnej w UGW.

\footnotetext{
"Sopocka Szkoła Wyższa, juliusz.gizynski@gmail.com
} 


\section{MIEJSCE SALDA STRUKTURALNEGO W NADZORZE FISKALNYM STREFY EURO}

Polityka fiskalna w strefie euro jest prowadzona samodzielnie przez jej kraje członkowskie. W celu ograniczenia ryzyka wynikającego z zachowania zdecentralizowanej polityki fiskalnej, na szczeblu unijnym wprowadzono wspólne reguły fiskalne i procedury ich egzekwowania (Ekonomiczne... 2014: 7). Najbardziej istotne z punktu widzenia dyscypliny fiskalnej w UGW są postanowienia Paktu Stabilności i Wzrostu (PSW). Stanowi on operacyjne rozwinięcie oraz uszczegółowienie odpowiednich zapisów wprowadzonych do prawa unijnego na mocy Traktatu z Maastrich w 1992 r. Działania dyscyplinujące, przewidziane zapisami PSW, dzielą się na dwie części: część prewencyjną (preventive arm), która ma ex ante zapobiegać powstawaniu nadmiernego deficytu budżetowego, tj. powyżej 3\% PKB, oraz część korekcyjną (corrective arm), która ma eliminować nadmierny deficyt ex post. PSW przyjęto formalnie w 1997 r., natomiast w czerwcu 2005 r. dokonano jego pierwszej reformy (Wierzba, Gostomski, Penczar, Liszewska, Górski, Giżyński, Małecka 2014: 104).

Wnioski wyciągnięte z ostrego kryzysu finansowego, który miał swój początek w strefie euro w drugiej połowie 2008 r., spowodowały uchwalenie szeregu nowych rozwiązań prawnych, reformujących PSW po raz drugi i trzeci. Rozwiązania te wprowadzono w $2011 \mathrm{r}$. za pomocą tzw. „Sześciopaku”. Z kolei w 2013 r. zaczął obowiązywać tzw. „Dwupak”. Dodatkowym wzmocnieniem jest umowa międzyrządowa, zwana Traktatem o stabilności, koordynacji i zarządzaniu w Unii Gospodarczej $i$ Walutowej, przyjęta w marcu 2012 r. Dalekosiężnym celem wzmocnionych reguł fiskalnych ma być przede wszystkim skłonienie rządzących na poziomie narodowym do prowadzenia rozważnej polityki fiskalnej.

Kluczową rolę wskaźnika oceny dyscyplinowania polityki fiskalnej w strefie euro pełni saldo strukturalne ${ }^{1}$. Jest to saldo dostosowane cyklicznie, bez uwzględnienia środków jednorazowych oraz tymczasowych (the cyclically - adjusted balance net of one - off measures) (Report on public... 2014: 28). Dane statystyczne wskazują, iż wysokość deficytów budżetowych zależy w znacznym stopniu od stanu koniunktury gospodarczej. Jeśli koniunktura się pogarsza, wówczas deficyty rosną, zaś w przypadku poprawy koniunktury, deficyty maleją. Przyczyny wahań deficytów budżetowych są jednak złożone (Wernik 2014: 88).

Do 2005 r. rola strukturalnego salda budżetowego w nadzorze unijnym była ograniczona do jego części prewencyjnej. Wynikało to z faktu, iż kraje członkowskie zobowiązały się do osiągania równowagi bądź nadwyżki w swoich budżetach narodowych w średnim okresie (medium - term objective, MTO). Sformułowanie „strukturalny” dotyczyło wówczas salda budżetowego dostosowanego cyklicznie. Część państw

${ }^{1}$ Szerzej na temat ewolucji koncepcji salda strukturalnego zobacz np. (Chalk: 2002: 4-10; Moździerz 2009: 54-57; Miklaszewicz 2012: 44-50). 
należących do strefy euro uciekało się jednak do tymczasowych bądź jednorazowych działań w zakresie polityki fiskalnej w celu zredukowania swoich deficytów. W związku z tym, w ramach pierwszej reformy Paktu Stabilności i Wzrostu, doprecyzowano ten wskaźnik, korygując go właśnie o działania redukujące deficyt. Ponadto poziom rocznego dostosowania salda strukturalnego w krajach członkowskich ustalono na poziomie 0,5 proc. PKB (The assessment of... 2014: 71), przy czym zobligowano te kraje do wprowadzania większego dostosowania strukturalnego w czasach dobrej koniunktury oraz mniejszego, gdy jest ona słabsza (Box 8:... 2015: 57).

Od 2005 r. saldo strukturalne odgrywa istotną rolę w systemie zarządzania polityką fiskalną w UGW. Za jego pomocą możliwe jest oszacowanie rozmiaru działań konsolidacyjnych, wprowadzanych przez kraje członkowskie oraz rozpoznanie rezultatów tych działań. Ponadto, cele budżetowe wyrażane są w wielkościach strukturalnych zarówno w ramach części prewencyjnej, jak i korekcyjnej Paktu (Report on public... 2014: 28).

Mimo powyższych zalet, wewnętrzna relacja salda strukturalnego do PKB może zakłócić ocenę podejmowanych działań fiskalnych przez kraje strefy euro. Do zniekształcenia tego salda, niezwiązanego z efektami prowadzonej polityki fiskalnej przez te kraje, doszło w czasie kryzysu oraz późniejszych nierównowag makroekonomicznych. Trudności sprawiało także oszacowanie potencjalnej produkcji (Report on public... 2014: 28). Dochodziło również do takich sytuacji, w których spowolnienie gospodarcze powodowało obniżenie deficytu rzeczywistego w stosunku do deficytu strukturalnego (Wernik 2014: 90).

Od 2011 r. koncepcja salda strukturalnego zaczęła nabierać nowego znaczenia. Kryzys finansowo-gospodarczy spowodował radykalne zmiany w poszczególnych gospodarkach strefy euro. Dodatkowo uświadomił on zarządzającym polityką fiskalną w tej strefie potrzebę rewizji oraz udoskonalenia metodologii szacowania salda strukturalnego. Pierwszej rewizji danych, w oparciu o zmiany metodyczne, dokonano w lutym 2013 r., drugiej zaś w listopadzie 2014 r. (Report on public... 2014: 41).

\section{PODSTAWOWE ASPEKTY METODYCZNE SZACOWANIA SALDA STRUKTURALNEGO}

Metoda szacowania salda strukturalnego, na użytek wdrażania zapisów Paktu Stabilności i Wzrostu, została rozwinięta i dopracowana przez Komisję Europejską oraz Organizację Współpracy Gospodarczej i Rozwoju (Organization for Economic Co-operation and Development, OECD). W ramach tej metody komponent cykliczny salda budżetowego wynika z oszacowanej luki produktowej ${ }^{2}(G D P /$

${ }^{2} \mathrm{~W}$ tym kontekście luka produktowa jest różnicą pomiędzy potencjalną a rzeczywistą wielkością produkcji, zaś potencjalna produkcja to wielkość, która może być osiągnięta w przypadku, gdy gospodarka funkcjonuje w oparciu o wszystkie moce produkcyjne. 
output gap) oraz przyjętej całkowitej wrażliwości salda budżetowego sektora finansów publicznych w stosunku do wielkości produkcji.

Od 2013 r. wrażliwość salda budżetowego na zmiany luki produktowej opisuje pojedynczy, stały parametr zwany pół - elastycznością (semi - elasticity) (Report on public ... 2014: 41; The assessment of ... 2014: 73). Poprzednia metoda szacowania salda strukturalnego była oparta na zwykłym parametrze dotyczącym wrażliwości budżetowej (fiscal sensitivity). Według tej koncepcji, saldo skorygowane cyklicznie, a w konsekwencji saldo strukturalne, było wyrażone w procencie bieżącego PKB. Było to jedną z przyczyn wielu błędów w ocenie tego wskaźnika. Należy podkreślić, iż w ramach zaktualizowanej metody wykorzystuje się wielkość produkcji potencjalnej (Mourre, Isbasoiu, Paternoster, Salto 2013: 5).

Szacunki pół-elastyczności opiera się na wskaźnikach elastyczności pozycji budżetowych o charakterze cyklicznym - podatków, składek na ubezpieczenie społeczne czy świadczeń dla bezrobotnych - do agregatów makroekonomicznych, tzn. płac, zysków, prywatnej konsumpcji bądź bezrobocia. Do oszacowania tego parametru można również wykorzystać wskaźniki elastyczności agregatów makroekonomicznych do PKB. Powyższe elastyczności kształtują się średnio dość blisko jedności, co oznacza, że pół-elastyczność salda budżetowego do PKB jest bliska udziału cyklicznych dochodów i wydatków budżetowych w PKB. Dla strefy euro wynosi ona średnio 0,52 (The assessment of ... 2014: 73).

Mnożąc parametr pół-elastyczności przez zmieniającą się w czasie wartością luki produktowej otrzymamy komponent cykliczny salda budżetowego, wyrażony w procencie potencjalnego PKB. Pół-elastyczność wynika zaś z indywidualnych elastyczności dochodów i wydatków budżetowych oraz zestawu wag parametrów (zob. tabela 1). Należy podkreślić, iż wydatki związane z bezrobociem oraz dochody z podatku dochodowego od osób prawnych charakteryzują się najwyższą elastycznością. Nie są to jednak wielkości, które mają największy wpływ na wysokość parametrów fiskalnej pół-elastyczności w krajach UGW. Poszczególne elastyczności mają bowiem swoje wagi w całkowitych dochodach / wydatkach, a także w wagach tych dochodów / wydatków (zob. tabela 1). W tym względzie łączny efekt powyższych dwu wag parametrów jest dość skromny, szczególnie w porównaniu do takich pozycji budżetowych, jak: podatki pośrednie oraz składki na ubezpieczenie społeczne (Report on public... 2014: 44).

Fiskalna pół-elastyczność w strefie euro, jak już podkreślano, wynosi średnio 0,52 . W związku z tym, dla każdej 1 proc. luki między rzeczywistym a potencjalnym PKB, stosowny komponent cykliczny salda budżetowego będzie wynosił około $1 / 2$ proc. PKB (The assessment of ... 2014: 73). Należy podkreślić, iż komponent ten podąża ściśle za ruchem całkowitej luki produktowej. Tak więc w razie braku tymczasowych środków, saldo strukturalne jest zsynchronizowane z nieskorygowanym saldem budżetowym, gdy gospodarka funkcjonuje na poziomie potencjalnym (Fiscal developments 2014: 86). 
Z tabeli 1 wynika, iż fiskalna pół-elastyczność w poszczególnych krajach UGW kształtuje się w granicach od 0,38 do 0,65 . Świadczy to o sporej zmienności w cykliczności tego salda. Np. komponent cykliczny salda budżetowego, odpowiadający 1 proc. luce produktowej, będzie równał się bądź przekraczał wartość 0,6 proc. PKB w takich krajach, jak: Belgia, Francja i Holandia. Natomiast na Łotwie, Litwie oraz Słowacji wskaźnik ten będzie oscylował poniżej oraz blisko wartości 0,4 proc. PKB.

Analizując poszczególne subkomponenty wskaźnika pół-elastyczności salda budżetowego, należy stwierdzić, iż przeciętna pół-elastyczność dochodów jest bliska zeru. W krajach strefy euro mieści się ona $w$ granicach od $-0,03$ do 0,07 (zob. tabela 1 ). Wynika to $\mathrm{z}$ faktu, że dochody budżetowe są prawie tak samo cykliczne jak PKB, wyłączając dochody niepodatkowe. Dlatego oczekuje się, iż wskaźnik dochodów do PKB będzie kształtował się zasadniczo na stałym poziomie w okresie normalnego cyklu koniunkturalnego. Szczególnie dotyczy to krajów członkowskich, w których udział dochodów niepodatkowych jest relatywnie niski (Report on public... 2014: 44).

Natomiast pół-elastyczność wydatków budżetowych w krajach UGW mieści się w granicach od $-0,39$ do $-0,60$ (zob. tabela 1). Średnia jej wartość wynosi zaś około $-0,5$. Elastyczność wydatków stanowi więc większą część dysproporcji w fiskalnej pół-elastyczności krajów członkowskich. Zasadniczo jej wartość odpowiada udziałowi całkowitych wydatków w PKB. Wynika to z faktu, że elastyczność wydatków do luki produktowej jest bliska zeru. Zakłada się bowiem, że jedynym wydatkiem budżetowym zmiennym w czasie cyklu koniunkturalnego są świadczenia dla bezrobotnych, a ich udział w całkowitych wydatkach jest niewielki. W rezultacie oczekuje się, że wskaźnik wydatków budżetowych do PKB będzie zmieniał się prawie w takiej samej proporcji jak luka produktowa (Report on public... 2014: 44-45).

W krajach należących do strefy euro, indywidualne elastyczności poszczególnych kategorii dochodów i wydatków budżetowych w odniesieniu do luki produktowej są następstwem gospodarczych oczekiwań (Report on public... 2014: 43). W tabeli 2. zaprezentowano wielkości tych elastyczności. Należy podkreślić, iż wielkości poszczególnych wskaźników w tych krajach są zróżnicowane.

Najwyższą cyklicznością charakteryzują się wpływy z podatków dochodowych od osób prawnych. Wpływy te są mocno skorelowane z zyskami osiąganymi przez przedsiębiorstwa na skutek wahań w gospodarce. W czasie cyklu udział firm, które nie osiągają zysku bądź notują stratę, wzrasta. Powoduje to sytuację, że firmy nie płacą żadnego podatku dochodowego od osób prawnych. Dużą cyklicznością odznaczają się również wpływy z tytułu podatku dochodowego od osób fizycznych. Wynika to z faktu, iż znaczna część krajów członkowskich stosuje progresywne skale podatkowe. Mniej wrażliwe na cykl koniunkturalny są natomiast składki na ubezpieczenie społeczne, ponieważ koszty opłacenia siły roboczej nie są w pełni powiązane $\mathrm{z}$ wahaniami gospodarki. Natomiast elastyczność podatków pośrednich, równa jedności, wskazuje, że wpływy z tytułu tych podatków podążają zgodnie z wahaniami gospodarczymi (Report on public... 2014: 43). 
$\frac{\sqrt{0}}{\frac{\pi}{0}}$

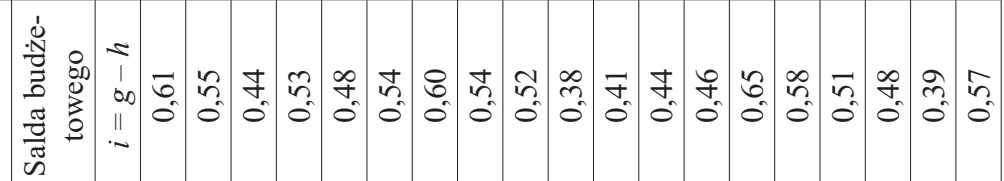

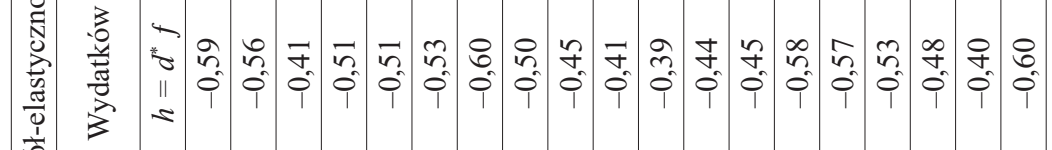
齐

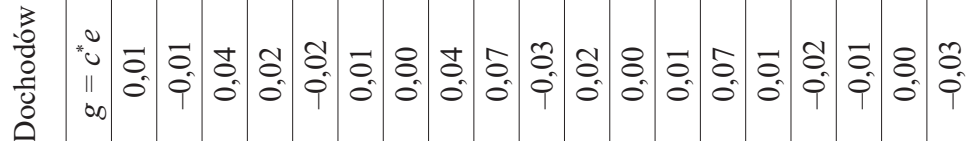

(8)

\section{ब}

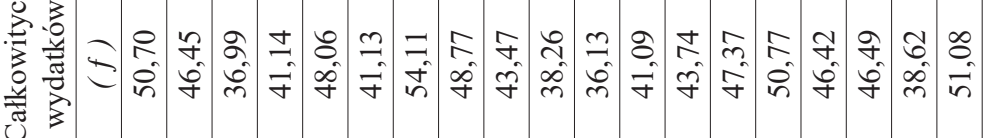

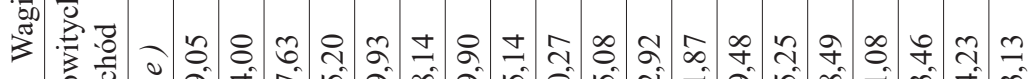

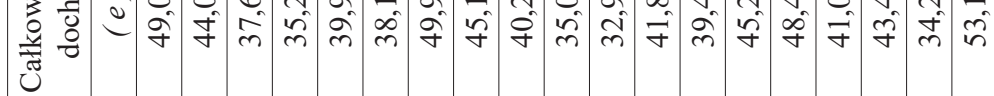

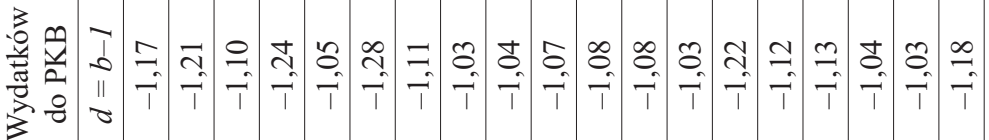

$\sum_{\substack{0 \\ 0}}^{0}$

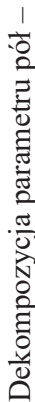

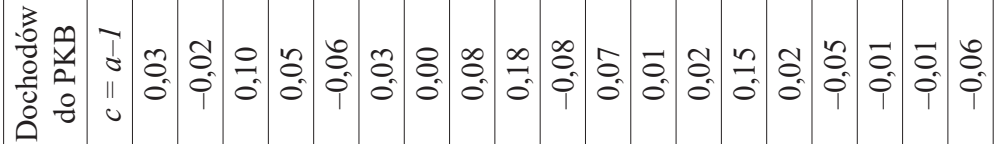

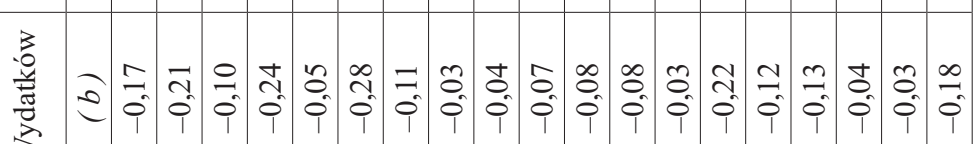

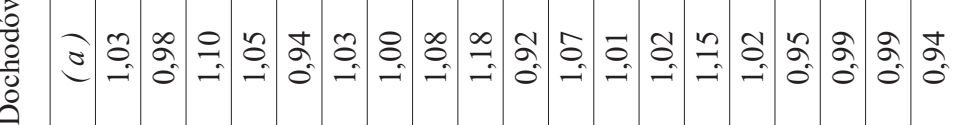

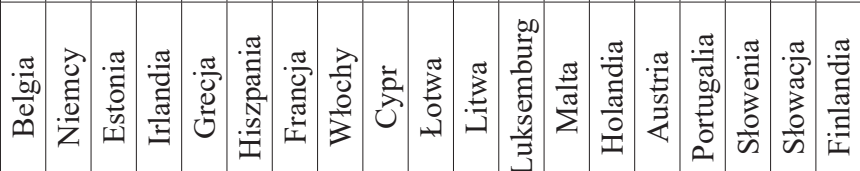


$\frac{\sqrt{\frac{\pi}{0}}}{\frac{\pi}{2}}$

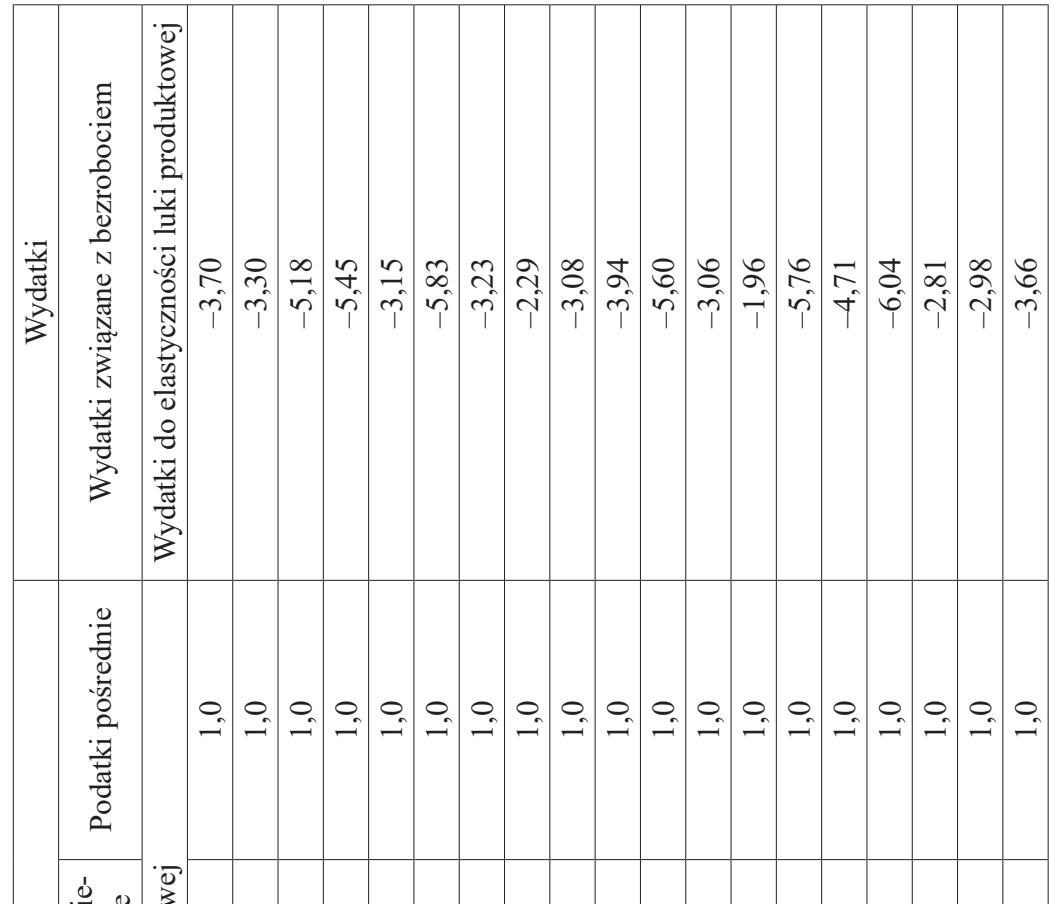

$\frac{3}{3}$

$:$

엄

긍

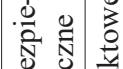

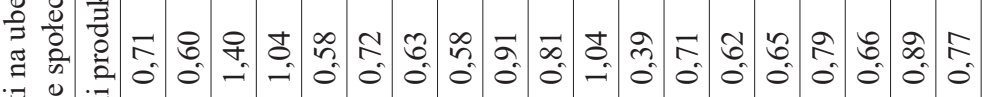
咅 $\cdot \frac{0}{\overline{0}} \cdot \vec{y}$

중

๑.

3.

กิ

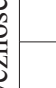

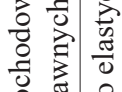

舟

范

$\dot{0} \rightarrow$

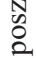

$\cdot \overline{0}$

赵

$\sum_{\frac{\pi}{0}}^{0}$

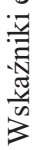

כ)

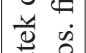

$\stackrel{\dot{\Xi}}{\dot{\Xi}}$
$\stackrel{\mathrm{O}}{\dot{\Xi}}$

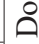

弯 $\frac{0}{0}$

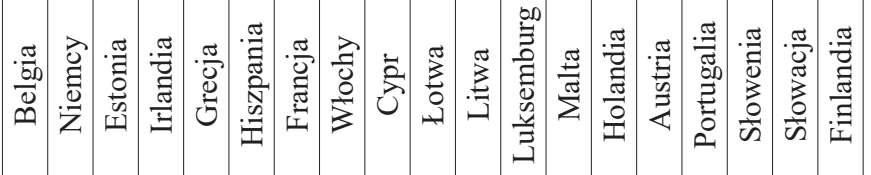


Do najważniejszych innowacji metodycznych, wprowadzonych w 2013 r. (Mourre, Isbasoiu, Paternoster, Salto 2013: 25-27) oraz 2014 r. (Mourre, Astarita, Princen 2014: 14-19), w szacowaniu salda strukturalnego, zaliczymy:

- wykorzystanie bardziej zdezagregowanych danych w kontekście podatku dochodowego od osób fizycznych, np. od zarobków wypłacanych za wykonywaną pracę (wages), od pensji miesięcznych (salaries), od samozatrudnienia (self-employment income) czy od dochodów kapitałowych (capital income), oraz oszacowanie elastyczności dla każdej zdezagregowanej pozycji dochodów z osobna;

- wykorzystanie bardziej zdezagregowanych danych w kontekście składek na ubezpieczenie społeczne, np. w podziale na składki płacone przez pracodawcę i pracownika, oraz oszacowanie elastyczności dla każdej pozycji z osobna;

- wykorzystanie zrewidowanych luk produktowych krajów UGW opartych na funkcji produkcji; do rewizji zastosowano nową metodologię, która opiera się na nieprzyspieszającej płace stopie bezrobocia (Non Accelerating Wage Rate of Unemployment, NAWRU);

- oszacowanie elastyczności dochodów do bazy dla podatku dochodowego od osób prawnych (wcześniej przyjmowano ją na poziomie jedności) oraz oszacowanie bezpośrednio elastyczności bazy do luki produktowej (wcześniej stosowano odwrotność elastyczności wynagrodzeń do luki produktowej);

- wsparcie założenia zerowej elastyczności dla dochodów niepodatkowych poprzez empiryczne szacunki.

Warto dodać, iż empirycznych szacunków dokonano dla każdej kategorii dochodów, a nawet dla tej, której elastyczność przyjęto na poziomie jedności (w metodologii przedstawionej w 2005 r.). Ponadto oszacowano elastyczność wydatków związanych z bezrobociem oraz wydatków zależnych od zysków. W przypadku pozostałych pozycji strony wydatkowej założono, że nie są one wrażliwe na cykliczność gospodarki (Report on public... 2014: 42-43).

\section{SALDO STRUKTURALNE W PAŃSTWACH STREFY EURO W OKRESIE WYCHODZENIA Z KRYZYSU}

Ewolucja salda strukturalnego jest istotnym wskaźnikiem oceny wysiłku fiskalnego, który podejmują kraje strefy euro w celu dyscyplinowania swojej polityki fiskalnej (The assessment of... 2014: 75). Podejmując się oceny globalnych rezultatów tej polityki, prowadzonej niezależnie przez kraje strefy euro w okresie 1999-2007, można ogólnie przyjąć, iż były one dość dobre, mimo braku woli politycznej w egzekwowaniu zapisów PSW. Sytuacja zmieniła się radykalnie wraz z rozszerzaniem się globalnego kryzysu finansowego. W latach 2009-2010 w strefie euro, jako całości, spadły dochody fiskalne przy jednoczesnym wzroście wydatków ogółem, a w tym szczególnie wydatków pierwotnych. W konsekwencji nastąpił znaczny wzrost m.in. wskaźnika deficytu budżetowego 
(Wierzba, Gostomski, Penczar, Liszewska, Górski, Giżyński, Małecka 2014: 110-111). Ponadto kraje strefy euro weszły w kryzys finansowy ze znacznymi deficytami strukturalnymi, co ograniczyło im pole do działań antycyklicznych oraz uniemożliwiło swobodne działanie automatycznych stabilizatorów koniunktury (Box 8:... 2015: 57).

W celu przezwyciężenia powyższej sytuacji poszczególne państwa UGW podjęły działania na szczeblu krajowym w zakresie konsolidacji fiskalnej i reform strukturalnych. Kryzys dowiódł, iż zapewnienie zdrowych finansów publicznych jest warunkiem niezbędnym do zachowania ogólnej stabilności makroekonomicznej oraz finansowej tych państw (Wierzba, Gostomski, Penczar, Liszewska, Górski, Giżyński, Małecka 2014: 110-111).

Analizując dane ${ }^{3} \mathrm{z}$ tabeli 3 należy stwierdzić, iż w okresie 2011-2013 państwa należące do strefy euro dokonały znaczących dostosowań w swojej polityce fiskalnej. Wysiłek fiskalny w strefie euro jako całości, mierzony poprawą salda strukturalnego w stosunku do roku poprzedniego, w roku 2011 wyniósł 0,7 pkt.\%, w 2012 r. aż 1,54 pkt.\%., a w 2013 r. 0,87 pkt.\%. Według prognozy z maja 2015 r., poprawa strukturalna w 2014 r. wyniosła 0,3 pkt.\%.

$\mathrm{Z}$ powyższych danych wynika, iż tempo konsolidacji fiskalnej w krajach strefy euro wyraźnie spadło w 2014 r., częściowo odzwierciedlając postęp, który kraje te osiągnęły w poprzednich latach. W celu zapewnienia stabilnego poziomu finansów publicznych, większość krajów członkowskich powinna kontynuować swoje wysiłki fiskalne zgodnie ze wzmocnionymi ramami zarządzania fiskalnego (Raport Roczny ... 2015: 36). Warto dodać, iż w ostatnich latach trwałą nadwyżkę strukturalną można zaobserwować jedynie w dwu krajach UGW, tj. w Niemczech i w Luksemburgu. Pozostałe kraje notują częściej deficyty niż nadwyżki. Na koniec 2014 r. deficyt strukturalny wciąż utrzymywał się w 14 krajach UGW, z czego w Belgii, w Irlandii, we Francji oraz na Malcie wynosił on powyżej $2,5 \%$ PKB (zob. tabela 3 ).

Z kolei w 2015 r. wskaźnik salda strukturalnego w strefie euro jako całości, według ostatniej prognozy, nie ulegnie poprawie, nieznacznie wzrastając o 0,04 pkt.\%, tj. do poziomu $-0,87 \%$ PKB. W 2016 r. może on się pogorszyć, w stosunku do 2015 r., o blisko 0,2 pkt.\% PKB.

Według szacunków Europejskiego Banku Centralnego, saldo strukturalne w strefie euro ma pozostać na niezmienionym poziomie do $2017 \mathrm{r}$. Wynika to $\mathrm{z}$ faktu, iż konsolidacja osiągnięta po stronie wydatkowej budżetów ma zostać znacznie skompensowana cięciami w podatkach pośrednich oraz w składkach na ubezpieczenie społeczne (Fiscal developments 2015: 29).

${ }^{3}$ Dane na temat wysokości salda strukturalnego sprzed 2010 r., oszacowane w oparciu o metodologię ESA 2010, nie są dostępne. 
Saldo strukturalne w krajach strefy euro w latach 2010 - 2016, w \% PKB

\begin{tabular}{|c|c|c|c|c|c|c|c|}
\hline & 2010 & 2011 & 2012 & 2013 & 2014 & $2015^{\mathrm{A}}$ & $2016^{\mathrm{A}}$ \\
\hline $\begin{array}{c}\text { Strefa } \\
\text { euro }\end{array}$ & $-4,24$ & $-3,54$ & $-2,00$ & $-1,13$ & $-0,83$ & $-0,87$ & $-1,06$ \\
\hline Belgia & $-3,69$ & $-3,77$ & $-3,14$ & $-2,65$ & $-2,77$ & $-2,31$ & $-2,13$ \\
\hline Niemcy & $-2,04$ & $-1,20$ & 0,15 & 0,77 & 1,20 & 0,99 & 0,65 \\
\hline Estonia & 0,32 & $-0,04$ & $-0,23$ & $-0,77$ & 0,16 & $-0,38$ & $-0,65$ \\
\hline Irlandia & $-8,86$ & $-8,12$ & $-7,21$ & $-4,91$ & $-4,08$ & $-3,58$ & $-3,32$ \\
\hline Grecja & $-9,85$ & $-6,32$ & $-0,56$ & 2,16 & 0,43 & $-1,41$ & $-2,33$ \\
\hline Hiszpania & $-6,93$ & $-6,12$ & $-3,42$ & $-2,08$ & $-1,95$ & $-2,37$ & $-2,57$ \\
\hline Francja & $-5,84$ & $-5,01$ & $-4,23$ & $-3,24$ & $-2,56$ & $-2,28$ & $-2,30$ \\
\hline Włochy & $-3,28$ & $-3,28$ & $-1,27$ & $-0,85$ & $-0,94$ & $-0,65$ & $-0,82$ \\
\hline Cypr & $-5,11$ & $-5,51$ & $-5,21$ & $-2,20$ & 1,46 & 0,41 & $-0,02$ \\
\hline Lotwa & $-2,01$ & $-0,95$ & 0,04 & $-1,02$ & $-1,64$ & $-1,92$ & $-2,18$ \\
\hline Litwa & $-3,36$ & $-3,71$ & $-2,73$ & $-2,30$ & $-1,18$ & $-1,90$ & $-1,17$ \\
\hline $\begin{array}{l}\text { Luksem- } \\
\text { burg }\end{array}$ & 0,35 & 1,03 & 1,81 & 2,49 & 1,62 & 0,59 & 0,38 \\
\hline Malta & $-4,15$ & $-2,90$ & $-3,90$ & $-2,63$ & $-2,61$ & $-2,15$ & $-1,59$ \\
\hline Holandia & $-3,78$ & $-3,80$ & $-2,20$ & $-0,61$ & $-0,23$ & $-0,33$ & $-0,45$ \\
\hline Austria & $-2,97$ & $-2,41$ & $-1,75$ & $-1,09$ & $-0,39$ & $-0,76$ & $-1,36$ \\
\hline Portugalia & $-7,61$ & $-5,65$ & $-2,43$ & $-1,71$ & $-0,76$ & $-1,55$ & $-2,13$ \\
\hline Słowenia & $-4,62$ & $-4,91$ & $-2,09$ & $-2,20$ & $-2,46$ & $-2,35$ & $-2,89$ \\
\hline Słowacja & $-7,16$ & $-3,99$ & $-3,38$ & $-1,38$ & $-2,02$ & $-1,86$ & $-1,84$ \\
\hline Finlandia & $-1,10$ & $-0,82$ & $-1,09$ & $-0,80$ & $-1,56$ & $-1,76$ & $-2,15$ \\
\hline
\end{tabular}

${ }^{\text {A }}$ prognoza wiosenna 2015 (aktualizacja: 5.05.2015).

Źródło: (European Commission 2015a).

Należy jednak podkreślić, iż w przeszłości dochodziło do zawyżenia wysiłku fiskalnego w niektórych krajach UGW. Saldo strukturalne więc nie zawsze jest wiarygodnym wskaźnikiem oceny tego wysiłku, szczególnie w środowisku, gdzie zachodzą gwałtowne zmiany warunków gospodarczych. Niepewność towarzysząca tym szacunkom najczęściej zmniejsza się, im bliżej prognozowanego roku (Kamps, De Stefani, Leiner-Killinger, Rüffer, Sondermann 2014: 14).

O tym, że kraje członkowskie podejmują wysiłki na rzecz konsolidacji fiskalnej świadczy to, ile $\mathrm{z}$ nich jest poddanych procedurze nadmiernego deficytu. 
Warto przypomnieć, iż na koniec 2010 r. procedura ta była otwarta wobec 15 z 16 członków UGW. Natomiast z końcem czerwca 2015 r. było to 7 ówczesnych krajów członkowskich, czyli mniej niż połowa. ${ }^{4}$

Mimo prawdopodobnego spadku wysiłku strukturalnego w strefie euro już od 2015 r., prognoza Komisji Europejskiej z wiosny 2015 r. wskazuje, że wszystkie kraje Unii Gospodarczej i Walutowej (oprócz Hiszpanii), poddane obecnie procedurze nadmiernego deficytu, są na właściwej drodze do wyjścia z tej procedury o ustalonym czasie. Wpływ na taką sytuację ma spadający deficyt rzeczywisty, poddany fazie cyklu koniunkturalnego (Fiscal developments 2015: 30).

$\mathrm{W}$ ostatnich latach na wysokość salda strukturalnego w strefie euro mogły wpływać różne niecykliczne czynniki. Możemy do nich zaliczyć m.in.:

- przyspieszone bądź opóźnione wpływy z podatków;

- strukturę systemu podatkowego i zasady rachunkowości np. zarządczej;

- udział niezarejestrowanej produkcji;

- okres przebywania poszczególnych osób na świadczeniu dla bezrobotnych;

- wyższe wydatki na emerytury i opiekę zdrowotną na skutek starzenia się ludności;

- wydatki na obsługę długu publicznego (The assessment of ... 2014: 74-75).

Warto dodać, że wahania PKB nie mają większego wpływu na wysokość wskaźnika salda strukturalnego. Może ono jednak wzrosnąć, gdy deficyt strukturalny jest znaczny, a PKB mocno się kurczy (bądź wzrasta) (The assessment of... 2014: 75).

$\mathrm{Z}$ pewnością wzmocnienie nadzoru fiskalnego w strefie euro przed kryzysem przyczyniłoby się do bardziej rozważnej polityki fiskalnej jej krajów członkowskich, szczególnie poprzez silniejsze wymogi w odniesieniu do strukturalnych pozycji fiskalnych w tych krajach oraz do ograniczenia wzrostu ich realnych wydatków budżetowych. Mimo wprowadzonych zmian w tym nadzorze, wciąż cechuje się on wieloma słabościami, szczególnie dotyczy to salda strukturalnego ${ }^{5}$, którego wiarygodność, jako rzeczywistego wskaźnika nadzoru polityki fiskalnej w UGW, nie jest wystarczająca (Kamps, De Stefani, Leiner-Killinger, Rüffer, Sondermann 2014: 21). Ponadto wskazówki ${ }^{6}$ Komisji Europejskiej, wydane w formie komunikatu w dniu 13 stycznia 2015 r., wyjaśniające i rozszerzające elastyczność w stosowaniu zapisów PSW, mogą dodatkowo spowolnić postęp w osiąganiu celów MTO przez kraje UGW. Mogą one także

${ }^{4} \mathrm{Na}$ dzień 30 czerwca 2015 r. strefa euro liczy 19 członków. W 2011 r. do UGW dołączyła Estonia, w 2014 r. Łotwa, a w 2015 r. Litwa. Kraje te, po przystąpieniu do unii walutowej, nie były poddane procedurze nadmiernego deficytu (European Commission 2015b).

${ }^{5} \mathrm{~W}$ następstwie reformy PSW z 2011 r. Komisja Europejska zaproponowała alternatywne wskaźniki oceny wysiłku fiskalnego w krajach UGW. Nie są one jednak pozbawione wad. Szerzej zob. (The assessment of ... 2014: 72, 77-82).

${ }^{6}$ Wskazówki te dotyczą trzech głównych obszarów: podejścia do reform strukturalnych, inwestycji oraz warunków koniunkturalnych. Szerzej na temat ich oceny zob. np. (Box 7:... 2015: 33-35). 
doprowadzić do dalszych znaczących oraz długotrwałych odchyleń tych krajów od ścieżki dostosowawczej do ich celów MTO, co może zwiększyć ryzyko utrzymania ich wskaźników długu publicznego na zrównoważonym poziomie (Box 8:... 2015: 59). Dlatego niezwykle ważne jest uzupełnienie analizy o inne wskaźniki oceny, które lepiej zdiagnozują podstawowe nierównowagi w czasie rzeczywistym (Kamps, De Stefani, Leiner-Killinger, Rüffer, Sondermann 2014: 21).

\section{PODSUMOWANIE}

Saldo strukturalne jest głównym wskaźnikiem oceny dyscyplinowania polityki fiskalnej w krajach strefy euro. Od 2005 r. za jego pomocą możliwe jest oszacowanie rozmiarów działań, podejmowanych przez kraje członkowskie w zakresie konsolidacji fiskalnej oraz rozpoznanie rezultatów tych działań. $\mathrm{Z}$ biegiem lat okazało się, iż metodologia szacowania tego salda stosowana w nadzorze fiskalnym strefy euro nie jest doskonała. Dlatego zdecydowano się na jej udoskonalenie w latach 2013 i 2014. Z kolei oceniając globalne rezultaty polityki fiskalnej w strefie euro w początkowych latach jej funkcjonowania, można ogólnie przyjąć, iż były one zadowalające. Sytuacja zmieniła się jednak w 2008 r., wraz z rozszerzaniem się globalnego kryzysu finansowego. Wówczas okazało się, iż kraje członkowskie weszły w ten kryzys ze znacznymi deficytami strukturalnymi, co zobligowało ich rządzących do skutecznych działań, łagodzących jego skutki. W celu naprawy tej sytuacji kraje strefy euro podjęły działania na rzecz konsolidacji fiskalnej i reform strukturalnych. Dzięki tym działaniom udało się im, w okresie 2011-2013, obniżyć znacznie swoje deficyty strukturalne. Wiele $\mathrm{z}$ nich opuściło również procedurę nadmiernego deficytu.

Biorąc pod uwagę fakt, iż poprawa strukturalnych pozycji budżetowych w krajach UGW jest dość trudna, występuje ryzyko powtórzenia błędów z okresu sprzed kryzysu, kiedy korekty w nominalnych saldach budżetowych okazały się nietrwałe. $Z$ uwagi na fakt, że cykliczna poprawa nabiera tempa, niezwykle ważne będzie zwiększenie nacisku na stabilność wskaźników zadłużenia oraz wznowienie konsolidacji fiskalnej w celu osiągnięcia postępu w realizacji celów MTO we wszystkich tych krajach, gdzie utrzymuje się potrzeba tej konsolidacji (Fiscal developments 2015: 30). Jeśli kraje należące do strefy euro nie zdołają przywrócić fiskalnych zabezpieczeń (fiscal buffers) w odpowiednim czasie, będą one źle przygotowane na następstwa negatywnych szoków ekonomicznych. Właśnie wówczas stabilna sytuacja fiskalna jest najbardziej pożądana (Box 8:... 2015: 59). 


\section{BIBLIOGRAFIA}

Box 7: Flexibility within the Stability and Growth Pact (2015), ECB, "Economic Bulletin", no. 1, p. 33-35.

Box 8: The effectiveness of the medium - term budgetary objective as an anchor of fiscal policies (2015), ECB, "Economic Bulletin", no. 4, p. 57-59.

Chalk N. (2002), Structural balances and all that: which indicators to use in assessing fiscal policy, IMF “Working Paper", June, no. 02/101.

Ekonomiczne wyzwania integracji Polski ze strefa euro (2014), NBP, Warszawa.

European Commission (2015a), AMECO, http://ec.europa.eu/economy_finance/ameco/user/serie/ SelectSerie. cfm, (dostęp: 1.07.2015).

European Commission (2015b), EU economic governance, http://ec.europa.eu/economy_finance/ economic governance/sgp/corrective arm/index_en.htm, (dostęp: 30.07.2015).

European Commission (2015c), Statistical Annex of European Economy, Spring.

Fiscal developments (2014), ECB “Monthly Bulletin”, September, p. 84-94.

Fiscal developments (2015), ECB, "Economic Bulletin", no. 4, p. 29-30.

Kamps C., De Stefani R., Leiner-Killinger N., Rüffer R., Sondermann D. (2014), The identification of fiscal and macroeconomic imbalances - unexploited synergies under the strengthened EU governance framework, ECB, "Occasional Paper Series", November, no. 157.

Miklaszewicz S. (2012), Deficyt budżetowy w krajach strefy euro, Oficyna Wydawnicza SGH, Warszawa.

Mourre G., Isbasoiu G.M., Paternoster D., Salto M. (2013), The cyclically - adjusted budget balance used in the EU fiscal framework: an update, "European Economy: Economic Papers", Brussels, March, no. 478.

Mourre G., Astarita C., Princen S. (2014), Adjusting the budget balance for the business cycle: the EU methodology, "European Economy: Economic Papers", Brussels, November, no. 536.

Moździerz A. (2009), Nierównowaga finansów publicznych, PWE, Warszawa.

Raport Roczny 2014 (2015), ECB, Frankfurt nad Menem.

Report on public finances in EMU - 2014 (2014), European Commission, "European Economy", no. 9.

The assessment of fiscal effort (2014), ECB “Monthly Bulletin”, October, p. 69-82.

Wernik A. (2014), Finanse publiczne, PWE, Warszawa.

Wierzba R., Gostomski E., Penczar M., Liszewska M., Górski P., Giżyński J., Małecka E. (2014), Polski sektor bankowy wobec wyzwań zwiąanych z kryzysem finansowym w strefie euro, Wydział Zarządzania UG, Sopot.

\section{Juliusz Giżyński}

\section{STRUCTURAL BALANCE AS AN INDICATOR OF THE ASSESSMENT OF FISCAL POLICY IN THE EURO AREA COUNTRIES}

\footnotetext{
Abstract. The main aim of this article is to submit an idea of the structural balance within the euro area fiscal surveillance framework, characterising its main methodological aspects and analysing the level of structural balance in the euro area countries in the time of recovery from the financial crisis. Since the first reform of the Stability and Growth Pact, which took place in 2005,
} 
structural balance has played the key role as an indicator of fiscal surveillance in the euro area. This balance is cyclically adjusted net of one - off and temporary measures. It enables to estimate the level of fiscal consolidation measures, which are being introduced by the euro area countries, and recognise the results of the actions taken.

Keywords: structural balance, euro area, fiscal effort. 